\title{
Salmonella spp. in Meat-type Quails (Coturnix coturnix coturnix) in the State of São Paulo, Brazil

\section{nAuthor(s)}

Freitas Neto OC de ${ }^{1 *}$

Angela $\mathrm{HL} \mathrm{da}$

Soares $\mathrm{NM}^{2}$

Guastalli $\mathrm{EAL}^{2}$

Almeida AM de ${ }^{1}$

Berchieri Junior $A^{1}$

Universidade Estadual Paulista - Campus de Jaboticabal, Departamento de Patologia Veterinária, Via de acesso Paulo Donato Castellane - SN - CEP: 14884-900, Jaboticabal, São Paulo, Brasil.

2 Instituto Biológico, Unidade de Pesquisa e Desenvolvimento de Bastos, Avenida Gaspar Ricardo - No 1700 - CEP: 17690000, Bastos, São Paulo, Brasil.

\section{-Mail Adress}

* Corresponding author e-mail address E-mail: oliveirocaetano@yahoo.com.br

\section{घKeywords}

Carcass, meat-type quails, Salmonella spp., processing plant.

\section{ABSTRACT}

In the present study Salmonella spp. was surveyed in four flocks of meat-type quails reared in a farm that also had processing plant on site, located in the region of Bastos, state of São Paulo, Brazil. Meconium samples of one-day-old quail chicks were collected from transport cardboard boxes. Cecal content was collected on days 7, 14, 21, 28 and 35 of rearing. At 36 days of age, birds were slaughtered in the farm's processing plant, where two samples of water from the scalding and the chilling tanks and four carcasses per flock were collected. All samples were examined for Salmonella spp. using traditional bacteriological methods. Salmonella spp. was present in meconium samples of three flocks and in cecal feces of the four flocks. This bacterium was also isolated in the chiller water and in the carcasses of three of the evaluated flocks and in the scalding water of one flock. In this study, $S$. enterica subspecies enterica 4, 5, 12; S. Corvalis; S. Give; S. Lexington; S. Minnesota; S. Schwarzengrund; S. Rissen and S. Typhimurium were the eight serovars identified.

\section{INTRODUCTION}

Quail farming was introduced in Brazil in the early 1960s for egg production purposes. During the last decade, quail meat production has also become an alternative for the Brazilian poultry sector. Due to special features, such as low initial investments, need of small areas, easy management and fast financial returns, quail production has expanded in Brazil.

As well as the industrial production of other domestic poultry, quail meat production has benefitted from genetic improvement, better feed efficiency and the use of modern housing facilities that allow rearing quails at high densities. However, some of these factors have also favored the entrance and dissemination of avian pathogens, such Salmonella spp. (Burkholder et al., 2008; Van Hoorebeke et al., 2011). General biosecurity and hygiene measures adopted in poultry farms and processing plants have reduced, but not prevented the presence of Salmonella spp. (Davies et al., 2003; Wegner et al., 2003).

There are three kinds of avian salmonellosis. The chicken-adapted Salmonella serovar Gallinarum biovars Pullorum and Gallinarum are responsible for pullorum disease and fowl typhoid, respectively (Barrow \& Freitas Neto, 2011). In addition to these two clinically systemic salmonellosis, birds may also be infected by Salmonella paratyphoid serovars and develop clinical disease or may become asymptomatic carriers and potential sources of human salmonellosis (Gast, 2003; Gast et al., 2011). The question if avian salmonellosis is a problem in quail production today still needs to be answered, as literature reports on this subject are not conclusive (Edwards, 1936; Pourciau \& Springer, 1978; Helm et al., 1999; Kumar et al., 2001; Sander et al., 2001; Erdogrul et 
Freitas Neto OC de, Angela HL da, Soares NM, Guastalli EAL,

al., 2002; Takata et al., 2003; Aarestrup et al., 2005; McCrea et al., 2006).

During the last few decades, Brazilian researchers and public health authorities have studied and addressed the problems caused by Salmonella spp. in poultry; however, there are very few studies investigating Salmonella spp. in Brazilian quail production. It should be mentioned that the Brazilian quail flock is estimated in 7.3 million birds (meat and egg production), which are reared near and or even inside chicken egg producing farms. Therefore, studies to assess the presence of Salmonella spp. in quails could generate information to allow the establishment of programs to control Salmonella in poultry production and to prevent human foodborne diseases.

\section{MATERIAL AND METHODS}

\section{Quail farm and processing plant}

Salmonella spp. was surveyed in a quail farm, which also has a quail processing plant, located in the region of Bastos, state of São Paulo, Brazil.

\section{Sample collection}

Samples of four different flocks were collected on the farm. Meconium samples of one-day-old quail chicks were collected from transport cardboard boxes. Cecal feces were collected at 7, 14, 21, 28 and 35 days of rearing. Birds were processed at 36 days of age. During processing, two samples of water from the scalding and chilling tanks were collected. Four carcasses per flock were collected.

One day-old-quail chicks were transported to the farm in cardboard boxes containing 250 birds each. After birds were removed from the boxes and housed, the meconium present inside the transport box was collected using sterile swabs moisturized in $1 \%$ buffered peptone water (1\% BPW) (Oxoid, CM 0509). Each sample corresponded to a pool of five swabs (one swab per box). A total of 23 samples were analyzed.

Twenty samples of cecal feces (five per flock) were collected. Each sample corresponded to a pool of five drag swabs from the same flock taken from the quail litter. Swabs were then placed in sterile glass recipients containing $50 \mathrm{~mL}$ of $1 \%$ BPW.

During processing, two $500-\mathrm{mL}$ samples of the scalding water and two $500-\mathrm{mL}$ samples of the chilling water were collected from the tanks per flock and placed in sterile flasks. Additionally, at the end of the
Salmonella spp. in Meat-type Quails (Coturnix coturnix coturnix) in the State of São Paulo, Brazil

processing line, four packaged carcasses per flock were collected.

All flasks and carcasses were placed inside a thermal box with ice and submitted to the laboratory.

\section{Sample processing and analyses}

In the laboratory, carcasses were placed inside sterile plastic bags and washed with $250 \mathrm{~mL}$ of $1 \%$ BPW, and the liquid was poured into sterile glass flasks. Ten $\mathrm{mL}$ of water from the scalding and the chilling tanks were added to sterile glass flasks containing $90 \mathrm{~mL}$ of $1 \%$ BPW.

Flasks containing the samples in 1\% BPW were left at room temperature for one hour, and were then incubated overnight at $37{ }^{\circ} \mathrm{C}$. The next morning, 1.0 $\mathrm{mL}$ of the incubated liquid was transferred to tubes containing $10 \mathrm{~mL}$ of selenite broth (Oxoid, CM 395) plus novobiocin (Merial, 8041706) and $0.1 \mathrm{~mL}$ to tubes containing $10 \mathrm{~mL}$ of Rappaport-Vassiliadis broth (Oxoid, CM 669). Tubes were incubated overnight at $37{ }^{\circ} \mathrm{C}$ (Davies \& Wray, 1994). Subsequently, broths from all samples were plated on the following culture media: Brilliant Green agar (Oxoid, CM 0263) and Mac Conkey agar (Oxoid, CM 0115). Plates were incubated overnight at $37{ }^{\circ} \mathrm{C}$. Out of each plate, five typical colonies were seeded on triple Sugar Iron agar (Oxoid, CM 277) and in Lysine Iron agar (Oxoid, CM 381), which were incubated overnight at $37^{\circ} \mathrm{C}$ and submitted to serology using polyvalent sera against $\mathrm{O}$ and $\mathrm{H}$ Salmonella antigens. Isolates were either sent to Adolfo Lutz Institute, São Paulo, Brazil, or to Oswaldo Cruz Foundation (Fio-Cruz), Rio de Janeiro, Brazil for complete identification and serotyping.

\section{RESULTS}

Salmonella spp. was surveyed in meconium samples of one-day-old quail chicks collected from four flocks. Three flocks (75\%) were infected with Salmonella spp. (Table 1).

Table 1 - Salmonella serovars isolated from meconium samples of one-day-old quail chicks collected from transport cardboard boxes.

\begin{tabular}{ccccl}
\hline Flock & \multicolumn{2}{c}{ Number of } & Result & \\
\cline { 2 - 3 } & Boxes & Birds & & Serovars \\
\hline 1 & 33 & 8,250 & + & $\begin{array}{l}\text { Salmonella Rissen, } \\
\text { S. enterica subspecies } \\
\text { enterica 4, 5, 12 }\end{array}$ \\
\hline 2 & 36 & 9,000 & + & Salmonella Rissen \\
\hline 3 & 17 & 4,250 & + & Salmonella Lexington \\
\hline 4 & 28 & 7,000 & - & - \\
\hline
\end{tabular}


Table 2 presents the results of Salmonella serovars isolated from cecal feces collected from the litter of the four evaluated flocks. Salmonella spp. was detected in all flocks 4. Flock 4, which was negative for Salmonella spp. when meconium samples were examined, became positive during rearing.

Table 2 - Salmonella serovars isolated from cecal feces collected from the litter at different times in four flocks.

\begin{tabular}{|c|c|c|c|c|}
\hline \multirow{3}{*}{$\begin{array}{l}\text { Age } \\
\text { (days) }\end{array}$} & \multicolumn{4}{|c|}{ Flock } \\
\hline & 1 & 2 & 3 & 4 \\
\hline & & Serovars & & \\
\hline 7 & $\begin{array}{l}\text { S. Corvalis } \\
\text { S. Lexington }\end{array}$ & S. Lexington & $\begin{array}{l}\text { S. Corvalis } \\
\text { S. Lexington }\end{array}$ & S. Lexington \\
\hline 14 & S. Lexington & S. Lexington & S. Lexington & S. Lexington \\
\hline 21 & $\begin{array}{l}\text { S. Lexington } \\
\text { S. Corvalis }\end{array}$ & $\begin{array}{l}\text { S. Lexington } \\
\text { S. Minnesota }\end{array}$ & S. Lexington & S. Lexington \\
\hline 28 & S. Lexington & $\begin{array}{l}\text { S. Lexington } \\
\text { S. Corvalis }\end{array}$ & $\begin{array}{l}\text { S. Lexington } \\
\text { S. Schwarzengrund }\end{array}$ & $\begin{array}{l}\text { S. Lexington } \\
\text { S. Give }\end{array}$ \\
\hline 35 & $\begin{array}{l}\text { S. Lexington } \\
\text { S. Typhimurium }\end{array}$ & $\begin{array}{l}\text { S. Lexington } \\
\text { S. Corvalis }\end{array}$ & $\begin{array}{l}\text { S. Typhimurium } \\
\text { S. Corvalis }\end{array}$ & $\begin{array}{l}\text { S. Lexington } \\
\text { S. Minnesota }\end{array}$ \\
\hline
\end{tabular}

All Salmonella serovars isolated from the scalding and chilling tanks and from the processed carcasses are shown in Table 3. Salmonella Lexington was recovered from the chilling water and carcasses from flocks 2 and 3. In flock 2, this serovar was also isolated from the scalding tank. In flock 1, Salmonella Minnesota was recovered from the scalding water and the carcasses. All samples from flock 4 were negative for Salmonella spp.

Table 3 - Salmonella serovars isolated during processing from different samples.

\begin{tabular}{|c|c|c|c|c|}
\hline \multirow{3}{*}{ Kind of sample } & \multicolumn{4}{|c|}{ Flock } \\
\hline & 1 & 2 & 3 & 4 \\
\hline & \multicolumn{4}{|c|}{ Salmonella serovars } \\
\hline \multirow{2}{*}{$\begin{array}{l}\text { Scalding tank } \\
\text { water }\end{array}$} & \multirow[b]{2}{*}{ - } & S. Lexington & - & - \\
\hline & & - & - & - \\
\hline \multirow{2}{*}{$\begin{array}{l}\text { Chilling tank } \\
\text { water }\end{array}$} & S. Minnesota & S. Lexington & S. Lexington & - \\
\hline & - & - & - & - \\
\hline Carcasses & S. Minnesota & S. Lexington & S. Lexington & - \\
\hline
\end{tabular}

- Absence of Salmonella spp.

\section{DISCUSSION}

There is a strong consensus that any program designed to prevent foodborne salmonellosis has to start on the farm where poultry are reared. Quail production has expanded in Brazil; consequently, quail products (meat and eggs) have become increasingly popular among the Brazilian consumers. Most quail farms are located near or even inside chicken egg production farms and the dynamics of Salmonella spp. dissemination between these two avian species is currently unknown. Studies aiming at surveying Salmonella spp. in commercial quail farming provide information on the prevalence and epidemiology of this bacterium in this population. The information generated in those studies may aid the design of control programs, and, therefore, help to reduce cases of human foodborne diseases.

In the present study, three out of the four quail flocks examined at one day of age were infected with Salmonella spp. (Table 1). Commercial broiler and layer (Gallus gallus) flocks surveyed immediately after hatching, in the hatchery or in transport cardboard boxes, have shown to be infected with Salmonella spp. at rates ranging from $11 \%$ to $77 \%$ (Zancan et al. 2000; Gama et al. 2003), which is consistent with our results, where $75 \%$ of the quail flocks were already infected with Salmonella spp. when they arrived at the farm.

Salmonella spp. can be disseminated either vertically or horizontally in poultry production. Feedstuffs, the presence of rodents, and multiple flocks reared on a single litter batch play an important role in horizontal transmission (Rose et al., 2003; Carrique-Mas et al., 2008; Jones, 2011). Infection in the beginning of life makes the control of Salmonella spp. difficult because young birds are more susceptible to this bacterium and excrete microorganisms longer than older birds (Gama et al., 2003). The detection of Salmonella spp. during the rearing period (Table 2 ) is certainly related to their presence in day-old birds, but the re-use of litter in the evaluated farm may have contributed to the persistence of the microorganism until the time of slaughter.

Two out of the six Salmonella serovars detected on the farm were also found in the samples collected in the processing plant (Table 3). The scalding tank may spread Salmonella if the water is not agitated, feces builds up in the tank, or temperatures are not high enough to kill bacteria (Cox \& Pavic, 2010). The absence of Salmonella spp. in the scalding water samples collected from flocks 1,3 and 4 may be explained by the correct temperature of the scalding water (above $60^{\circ} \mathrm{C}$ ) when these three samples were collected. Salmonella spp. counts can be reduced up to $5.5 \mathrm{log}$ of colony forming units (CFU) $\mathrm{mL}$ when scalding water is at $60^{\circ} \mathrm{C}$ (Yang et al., 2001). 
The main sources of carcass contamination with Salmonella spp. during processing are considered to be head pulling and evisceration, when there may be leakage of crop content and intestinal rupture, respectively (Smith et al., 2007). Once contaminated during these steps, Salmonella spp. from one carcass can easily disseminate to other carcasses at chilling step. In order to reduce pathogen carryover in the chiller, sanitizers are traditionally added to chilling water (Hugas \& Tsigarida, 2008; Bauermeister et al., 2008). The persistence of Salmonella spp. in the chilling water and in the carcasses observed in the present study may be related to the evisceration and chilling steps.eTherefore, special care must be taken during these processing steps and perhaps additional measures should be adopted in the processing plant (e.g., the use of sanitizers in the chilling water, better calibration of the evisceration machine) to control or minimize this problem.

Salmonella Lexington has not been isolated in commercial birds in Brazil (Hofer et al., 1997). However, it was the most common serovar (Tables 1, 2 and 3) found in the current study. Its presence was also reported in samples of retail duck meat examined in Vietnam (Pham et al., 2005). Salmonella Corvalis was the second isolated serovar from quail cecal feces. Although this serovar is not common in Brazil, it was also the third isolated from samples analyzed in Tunisia between 1994 and 2004 (Benajssaum et al., 2007). In the present study, S. Minnesota was isolated from cecal feces samples, chilling water and carcasses; interestingly, it has rarely been reported in Brazil (Taunay et al., 1996; Michael et al., 2002). In the United States, this serovar was also isolated at low rates from human and animal sources between 1996 and 2006 (CDC, 2006).

$S$. Typhimurium is responsible for most of cases of avian paratyphoid salmonellosis (Gast, 2003). Consistent with the findings of the present study, this serovar was previously described in meat-type quail flocks (Kumar et al., 2001). S. Schwarzengrund is not frequent found in commercial poultry; however, it was isolated from cecal feces of quails in this study. It was one of the fifteen most frequently isolated serovars from human cases of foo borne diseases in Brazil (Fernandes et al., 2006).

In Finland, S. Rissen was one of the most frequent serovars isolated from birds in 2003 (Bangtrakulnonth et al., 2004). In Brazil, there are reports on the isolation of this serovar in samples from infected human beings betweem 1950 and 1990 (Taunay et al., 1996).
However, the risk of this serovar for the Brazilian population is mainly related to consumption of port, since it has been commonly isolated from pigs (Bessa et al., 2004). S. Give was responsible for an outbreak in infants in France in 2008, but in this case it was linked to an infant milk formula (Jourdan et al., 2008). In addition, it was also found in ostrich meat (Higgins et al., 1997) and in commercial broiler feces, feedstuffs and feeds (Hoffer et al., 1998). The results obtained in the present study demonstrated that quails reared under intensive production practices man be infected with Salmonella spp., as it is similarlynobserved in industrial broiler and layer production. Further studies are warranted to elucidate the relationship between Salmonella spp. and quails, and particularly on paratyphoid salmonellosis in this species and its possible importance as a human foodborne diseases.

\section{ACKNOWLEDGMENTS}

The authors would like to thank FAPESP and CNPq for their financial support.

\section{REFERENCES}

Aarestrup FM, Hasman H, Jensen LB. Resistant Salmonella virchow in quail products. Emerging Infectious Diseases 200511 1984-1985.

Bangtrakulnonth A, Pornreongwong S, Pulsrikarn C, Sawanpanyalert $P_{\imath}$ Hendriksen RS, Lo Fo Wong DM, Aarestrup FM. Salmonella serovars from humans and other sources in Thailand. Emerging Infectious Diseases $200410131-136$

Barrow PA, Freitas Neto OC. Pullorum disease and fowl typhoid -- new thoughts on old diseases: a review. Avian Pathology 201140 1-13.

Bauermeister LJ, Bowers JW, Townsend JC, McKee SR. Validating the efficacy of peracetic acid mixture as an antimicrobial in poultry chillers, Journal of Food Protection 200871 1119-1122.

Benajssaum BR, Gallasum N, Troudium BH, Belhadjum B, Belhadium AB. Trends in Salmonella enterica serotypes isolated from food, humans, animals and environment in Tunisia, 1994-2004. The Journal of Infection 200755 324-339.

Bessa MC, Costa M, Cardoso M. Prevalência de Salmonella em suínos abatidos em frigoríficos do Rio Grande do Sul. Pesquisa Veterinária Brasileira 200424 80-84

Burkholder $\mathrm{KM}$, Thompson $\mathrm{KL}$, Einstein $\mathrm{ME}$, Applegate $\mathrm{TJ}$, Patterson JA. Influence of stressors on normal intestinal microbiota, intestinal morphology, and susceptibility to Salmonella enteritidis colonization in broilers. Poultry Science 200887 1734-1741

Carrique-Mas JJ, Breslin M, Snow L, Arnold ME, Wales A, McLaren I, Davies $\mathrm{RH}$. Observations related to the Salmonella EU layer baseline survey in the United Kingdom: follow-up of positive flocks and sensitivity issues. Epidemiology and Infection 2008136 1537-1546.

Cox, JM, Pavic A. Advances in enterophatogen control in poultry production. Journal of Applied Microbiology 2010108 745-755. 


\section{Salmonella spp. in Meat-type Quails (Coturnix coturnix coturnix) in the State of São Paulo, Brazil}

Davies R, Liebana E, Breslin M. Investigation of the distribution and control of Salmonella enterica serovar Enteritidis PT6 in layer breeding and egg production. Avian Pathology 200332 225-237.

Erdogrul O, Ozkan N, Cakiroglu E. Salmonella enteritidis in quail eggs. Turkish Journal of Veterinary and Animal Sciences 200226 321-323.

Edwards PR. The occurrence of salmonella, oranienburg type, in an infection of quail. Journal of Bacteriology 193632 259-263.

Fernandes SA, Tavechio AT, Ghilardi ACR, Dias AMG, Almeida IA, Melo LCV. Salmonella serovars isolated from humans in São Paulo State, Brazil, 1996-2003. Revista do Instituto de Medicina Tropical de Sao Paulo 200648 174-189.

Gama NMSQ, Berchieri A, Fernandes AS. Ocorrence of Salmonella spp. in laying hens. Brazilian Journal of Poultry Science 20035 15-21.

Gast RK. Salmonella infectious. In: Sai, M, editor. Diseases of poultry. 11th ed. Ames: lowa States University Press; 2003. p 567-613.

Gast RK, Guraya R, Guard J, Holt PS. Frequency and Magnitude of Internal Organ Colonization Following Exposure of Laying Hens to Different Oral Doses of Salmonella enteritidis. International Journal of Poultry Science 201110 325-331.

Helm JD, Hines RK, Hill JE, Caver JA. Multiple drug-resistant Salmonella typhimurium DT104 and DT104b isolated in bobwhite quail (Colinus virginianus). Avian Disesaes 199943 788-7891.

Higgins R, Desilets A, Cantin M, Messeier S, Khakhria R, Ismail J, Mulvey MR, Daignault D, Caron H. Outbreak of Salmonella give in the province of Quebec, The Canadian Veterinary Journal 1997 38: 780-781.

Hofer E, Silva Filho SJ, Reis EMF. Prevalence of Salmonella serovars isolated from birds in Brazil. Pesquisa Veterinária Brasileira 199717 55-62

Hofer E, Silva SJF, Reis EMF. Sorovares de Salmonella isolados de matériasprimas e de ração para aves no Brasil. Pesquisa Veterinária Brasileira $19981821-27$

Hugas M, Tsigarida E. Pros and cons of carcass decontamination: the role of the European Food Safety Authority. Meat Science 200878 43-52.

Jones FTA. Review of practical Salmonella control measures in animal feed. The Journal of Applied Poultry Research 201120 102-113.

Jourdan N, Hello SL, Delmas G, Clouzeau J, Manteau C, Desaubliaux B, Chagnon V, Demare N. Nationwide outbreak of Salmonella enterica serotype Give infections in infantis in France, linked to infant milk formula. Eurosurveillance 200813 25-27.

Kumar S, Sadana JR, Mishra SK. Studies on clinical signs, growth response and haematological changes in Japanese quail (Coturnix coturnix japonica) infected with Salmonella typhimurium. Indian Journal of Poultry Science 200136 335-337.

McCrea BA, Tonooka KH, VanWorth C, Boggs CL, Atwill ER, Schrader JS. Prevalence of Campylobacter and Salmonella Species on Farm, After Transport, and at Processing in Specialty Market Poultry. Poultry Science 200685 136-143.

Michael GB, Simoneti R, Cardoso MR, Costa M. Salmonella serotypes isolated from a finishing swine farm in the south of Brazil. Ciência Rural 200232 525-527.

Phan TT, Khai LT, Ogasawara N, Tam NT, Okatani AT, Akiba M, Hayashidani $\mathrm{H}$. Contamination of Salmonella in retail meats and shrimps in the Mekong Delta, Vietnam. Journal of Food Protection 2005 68:10771080.

Pourciau SS, Springer WT. Frequency and duration of paratyphoid organism shedding by experimentally infected bobwhite quail (Colinus virginianus). Journal of wild Life Diseases 1978 14: 203-207.
Rose N, Mariani JP, Drouin P, Toux JY, Rose, V, Colin P. A decision-support system for Salmonella in broiler-chicken flocks. Preventive Veterinary Medicine 200359 27-42.

Sander J, Hudson CR, Dufour-Zavala L, Waltman WD, Lobsinger C, Thayer SG, Otalora R, Maurer JJ. Dynamics of Salmonella contamination in a commercial quail operation. Avian Diseases 2001 45: 1044-1049.

Smith DP, Northcutt JK, Cason JA, Hinton Jr A, Buhr RJ, Ingram KD. Effect of external or internal fecal contamination on numbers of bacteria on prechilled broiler carcasses. Poultry Science 2007; 86 1241-1244.

Takata T, Liang J, Nakano H, Yoshimura Y. Invasion of Salmonella enteritidis in the tissues of reproductive organs in laying Japanese quail: an immunocytochemical study. Poultry Science 2003; 82 1170-1173.

Taunay AE, Fernandes SA, Tavechio AT, Neves BC, Dias AMG, Irino K. The role of public health laboratory in the problem of salmonelosis in São Paulo, Brasil. Revista do Instituto de Medicina Tropical de Sao Paulo 199638 119-127.

Van Hoorebeke S, Van Immerseel F, Haesebrouck F, Ducatelle R, Dewulf J. The Influence of the Housing System on Salmonella Infections in Laying Hens: A Review. Zoonoses and Public Health 201158 304-311.

Wegener HC, Hald T, Lo Fo Wong D, Madsen M, Korsgaard H, Bager $F_{\text {, }}$ Gerner-Smidt P, Mølbak K. Salmonella control programs in Denmark. Emerging Infectious Diseases 20039 774-780.

Yang H, Li Y, Johnson MG. Survival and Death of Salmonella Typhimurium and Campylobacter jejuni in Processing Water and on Chicken Skin during Poultry Scalding and Chilling. Journal of Food Protection 2001 $64770-776$

Zancan FB, Berchieri Júnior A, Fernandes AS, Gama NMSQ. Salmonella spp investigation in transport box of day old birds. Brazilian Journal of Microbiology 200031 230-232. 
